\title{
Carbon Capture and Storage versus Renewable Energy: Comparing Emissions Reductions and Their Strategic Positions
}

\author{
— Evidence from China
}

\author{
Qiang Gao* \\ School of Economics and Management, Northwest \\ University, \\ 710127, Xi'an, China \\ 15249287116@163.com
}

\author{
Rong Kang \\ School of Economics and Management, Northwest \\ University, \\ 710127, Xi'an, China \\ kangrong@nwu.edu.cn
}

\begin{abstract}
In the face of increasing environmental problems, nations have designed and implemented a variety of methods to stabilize the climate. Carbon capture and storage (CCS) technology is intended to mitigate global warming by capturing, transporting, and sequestrating carbon dioxide $\left(\mathrm{CO}_{2}\right)$ to reduce greenhouse gas emissions; ensure energy security and reduce pollution, renewable energy technology has become an important choice for countries to ensure sustainable development, and they are both cited as important components of an energy development strategy. The role of renewable energy in $\mathrm{CO}_{2}$ emissions reductions has great potential, and its impact in mitigating the greenhouse effect has strategic significance. By comparing CCS technology and renewable energy technologies, including costs and effects of carbon dioxide emissions reductions, this paper indicates the strategic position China should take to promote the development of both CCS technology and renewable energy technologies, and provides a reference to formulate a suitable $\mathrm{CO}_{2}$ emissions reductions strategy.
\end{abstract}

Keywords-Carbon capture and storage technology; carbon capture, utilization and storage (CCUS) technology; renewable energy, carbon dioxide $\left(\mathrm{CO}_{2}\right)$ emissions reductions; comparison.

\section{INTRODUCTION}

Since the industrial revolution in the 1700 s, the widespread use of fossil fuels has greatly increased carbon dioxide emissions, and the recently recognized need to tackle global warming has made it crucially important to mitigate the effect of these greenhouse gases. CCS technology, which has been developing for nearly 30 years, has become an indispensable weapon in the fight to reduce greenhouse gas emissions. From the 1970s onwards, and especially in this century, renewable energy has become an important international choice in implementing sustainable development strategies; some countries have used legislation to promote the development of renewable energy, and have continued to reduce costs through technological innovation. Nearly 0 of the carbon-emitting of renewable energy make itself have huge role and potential in reducing greenhouse gas emissions. Not only can we avoid the risks which are posed by traditional energy sources, but we can also realize nearly 0 emissions of carbon dioxide, so that renewable energy technologies have realized a period of rapid development and are now internationally accepted.

But there is no clear solution to the strategic positioning between CCS and renewable energy in reducing carbon dioxide emissions. This paper introduces the development and current situation regarding CCS and renewable energy technologies in China, and analyzes the methods, advantages, and disadvantages of CCS and renewable energy technologies in carbon dioxide emissions reductions. It also examines the short-term and long-term roles of CCS and renewable energy technologies in the process of reducing carbon dioxide emissions and controlling global warming.

\section{THE STATUS OF CCS AND RENEWABLE ENERGY AND ITS SIGNIFICANCE IN REDUCING CARBON EMISSIONS}

CCS and renewable energy technologies have undergone a long period of development, and the achievements have been fruitful. They have significant implications for reducing carbon dioxide emissions, and better methods have not yet been found. Therefore, it is necessary to understand the history of the development of these technologies, the current situation, and the importance of reducing carbon dioxide emissions.

\section{A. The status of CCS (CCUS) and its significance in reducing carbon emissions}

MIT introduced CCS to the academic field by launching a project in 1989. The technology developed rapidly as it was seen as a viable method to tackle climate change and control greenhouse gas emissions. The International Energy Agency (IEA) identified CCS as a key technology that could limit global warming within two degrees Celsius by 2050. At the same time, the emissions of non-carbon dioxide greenhouse gases should not be neglected, which is crucial to the realization of the temperature control target. Due to CCS technology is consistent with the structure of existing energy systems and is less constrained by energy conditions; it is of particular interest in industrialized countries. The fifth assessment report of the International Climate Change Commission indicates that the cost of low carbonation would 
increase the long-term target of two degrees Celsius by $138 \%$ without this technology. The major energy consumers in the world have developed and experimented with CCS technology, carried out a series of demonstration and application projects, and have concluded it is an important strategic component of clean coal technology.

China, the world's largest emitter of greenhouse gases, using coal as a primary energy source, is saddled with a basic energy structure that will be difficult to change in the short term and faces the arduous task of decarbonization its economic growth. Since the Eleventh Five-Year Plan (2006 2010) was implemented, the Chinese government has made unprecedented efforts to transform the economic growth pattern to make it more sustainable and move towards a lowcarbon growth path. In the Thirteenth Five-Year Plan (2016 2020), the Chinese government announced a goal of reducing carbon intensity by 18\% compared to the base of 2015; up to 2020, the proportion of non-fossil fuel energy will reach $18 \%$. Effective control of carbon emissions from power, steel, building materials, and other key industries; promotion of lowcarbon development in energy, construction, transportation, and other key areas; support for the optimization of the development region to get the peak of carbon emissions; enhancing various low-carbon pilot projects; implementing the nearly 0 carbon emissions area pilot project; and controlling non-carbon dioxide greenhouse gas emissions, were also important elements of this plan[1].

In China, fossil fuels account for $85 \%$ of the basic energy supply, and coal contributes $70 \%$ of this total, with the electricity, heat, and industrial sectors dominated by this energy source. $\mathrm{CO}_{2}$ emissions from electricity and heat account for $50 \%$ of the country's $\mathrm{CO}_{2}$ emissions, with other industries accounting for $30 \%$ of the balance.

The IEA said the 2040 global 430GW power plant needed to use CCS technology, $60 \%$ of which are coal-fired power plants, and $75 \%$ of the world's coal-fired power plants which need to use this technology are in China[2]. Despite the largescale and rapid deployment of non-fossil fuels and low-carbon energy, coal will continue to be a major factor in the country's economic growth. CCS technology provides an irreplaceable advantage for China because it can help to mitigate climate change by cutting greenhouse gas emissions without substantially reducing the use of fossil fuels. Table 1 lists domestic CCS pilot projects in China.

TABLE I. DOMESTIC CCS PILOT PROJECTS IN CHINA TO THE END OF 2016[12]

\begin{tabular}{|c|c|c|c|}
\hline Item & Name of project & Starting Date & $\begin{array}{c}\text { Status in } \\
2016 \\
\end{array}$ \\
\hline 1 & $\begin{array}{l}\text { Research and Pilot of } \mathrm{CO}_{2}- \\
\text { EOR in CNPC Jilin Oilfield }\end{array}$ & 2007 & $\begin{array}{c}280,000 \\
\text { tons per } \\
\text { year }\end{array}$ \\
\hline 2 & $\begin{array}{l}\text { Pilot project in Sinopec } \\
\text { Shandong Shengli Oilfield }\end{array}$ & 2010 & $\begin{array}{c}\text { 40,000 } \\
\text { tons per } \\
\text { year }\end{array}$ \\
\hline 3 & $\begin{array}{c}\text { CCS pilot project in salty } \\
\text { water layer of China Shenhua } \\
\text { CTL }\end{array}$ & 2011 & $\begin{array}{l}100,000 \\
\text { tons per } \\
\text { year }\end{array}$ \\
\hline
\end{tabular}

\begin{tabular}{|c|c|c|c|}
\hline \multicolumn{4}{|c|}{ Cont.to TABLE I } \\
\hline 4 & $\begin{array}{l}\mathrm{CO}_{2} \text {-EOR project of Sinopec } \\
\text { in Zhongyuan Oilfield }\end{array}$ & 2008 & $\begin{array}{c}100,000 \\
\text { tons per } \\
\text { year }\end{array}$ \\
\hline 5 & $\begin{array}{l}\mathrm{CO}_{2} \text { enhanced coal bed gas } \\
\text { mining project of CUCBM }\end{array}$ & 2010 & $\begin{array}{c}1,000 \text { tons } \\
\text { per year }\end{array}$ \\
\hline 6 & $\begin{array}{c}\text { China Power Investment } \\
\text { Shuang Huai power plant } \\
\text { CCS pilot project in } \\
\text { Chongqing } \\
\end{array}$ & 2010 & $\begin{array}{l}10,000 \\
\text { tons per } \\
\text { year }\end{array}$ \\
\hline 7 & $\begin{array}{l}\text { Clean coal power systems } \\
\text { research facilities in } \\
\text { Lianyungang }\end{array}$ & 2011 & $\begin{array}{c}30,000 \\
\text { tons per } \\
\text { year }\end{array}$ \\
\hline 8 & $\begin{array}{l}\text { HUST research and pilot of } \\
\text { 35MWt of oxygen-enriched } \\
\text { combustion technology }\end{array}$ & 2011 & $\begin{array}{c}100,000 \\
\text { tons per } \\
\text { year }\end{array}$ \\
\hline 9 & $\begin{array}{l}\text { State Grid thermal power } \\
\text { plant in Tianjin Beitang }\end{array}$ & 2012 & $\begin{array}{l}20,000 \\
\text { tons per } \\
\text { year }\end{array}$ \\
\hline 10 & $\begin{array}{c}\text { China Huaneng Group } \\
\text { Gaobeidian }\end{array}$ & 2008 & $\begin{array}{l}3,000 \text { tons } \\
\text { per year }\end{array}$ \\
\hline 11 & $\begin{array}{c}\text { China Huaneng Group power } \\
\text { plant in Shidongkou }\end{array}$ & 2009 & $\begin{array}{c}120,000 \\
\text { tons per } \\
\text { year }\end{array}$ \\
\hline 12 & $\begin{array}{c}\text { China Huaneng Group IGCC } \\
\text { in Tianjin }\end{array}$ & $\begin{array}{c}\text { The Capture have } \\
\text { finished, the } \\
\text { storage was } \\
\text { delayed }\end{array}$ & $\begin{array}{l}100,000 \\
\text { tons per } \\
\text { year }\end{array}$ \\
\hline 13 & $\begin{array}{c}\text { Yanchang Group CCUS pilot } \\
\text { project }\end{array}$ & 2013 & $\begin{array}{c}50,000 \\
\text { tons per } \\
\text { year }\end{array}$ \\
\hline
\end{tabular}

Status of renewable energy and its significance in reducing carbon emissions

The development of renewable energy is crucial to sustainable development in China, and it also provides a way to circumvent the risks of traditional energy price fluctuations. In terms of sustainable development, the demand for reductions in $\mathrm{CO}_{2}$ emissions and concerns about future energy shortages and climate change has urged the government to adopt measures to promote renewable energy development.

In order to fulfill international commitments to deal with climate change and alleviate the problem of air pollution, China has actively promoted policy reforms in the renewable energy industry, cultivated the renewable energy market, and supported alternate energy sources such as photovoltaic and wind power, thus increasing the status of renewable energy domestically. BP estimates that renewable energy resources can be developed at about 3.6 billion ton standard coal/year[3]. By 2016, China had overtaken the United States as the world's largest producer and consumer of renewable energy[4] and, according to statistics from the National Energy Bureau, by the end of that year, 570 million $\mathrm{kw}$ of renewable energy generation capacity had been installed, accounting for $34.6 \%$ of the national total. Installed hydroelectric power was 332 million $\mathrm{kw}$, representing $20.2 \%$ of the total; wind power generated 149 million kw (9\%); PV power capacity was 77.42 million kw (4.7\%); and installed biomass power capacity amounted to 12.14 million $\mathrm{kw}$ (0.7\%). In 2016, including hydropower, renewable energy power consumption totaled 1.5058 trillion $\mathrm{kw}$, and accounted for $25.4 \%$ of national consumption, representing a $0.9 \%$ year-on-year increase [5].

Investments in renewable energy can effectively promote reductions in carbon emissions. Specifically, policies to guide 
these investments, optimize the investment structure, improve investment efficiency, and to stimulate effective coordination of incentive policies in areas related to technology, energy taxes, and financing, can act to stimulate the development of the renewable energy industry. These measures will support energy conservation, emissions reductions, and low-carbon economic development[6].

\section{III.COMPARING CCS TECHNOLOGY AND RENEWABLE ENERGY}

CCS technology and renewable energy are essential to $\mathrm{CO}_{2}$ emissions reductions, but the methods to achieve these reductions differ. This paper studies the cost of emissions reductions, the impacts on the energy structure and security, the byproducts of reduction, investment and operating costs, and so on.

\section{A. CCS technology and renewable energy emissions reductions per ton of $\mathrm{CO}_{2}$ and power generation cost comparison}

Table 2 shows the costs of renewable energy generation and emissions reductions, and Table 3 the cost reductions by CCS generation case. It can be seen from Table 2 that hydropower and wind power generation costs are relatively low, while biomass and photovoltaic power generation costs are higher. The cost of enhanced oil recovery(EOR) in Table 3 is negative and the cost of salt water layer is higher. With respect to costs of emissions reductions, renewable energy is generally better than CCS technology, and all the salt water layer and photovoltaic power (except for solar thermal energy) emissions reductions costs are positive and high. As a result, CCS technology is very limited in its emissions reductions potential due to its high cost if it is not applied in EOR.

TABLE II. RENEWABLE ENERGY GENERATION AND COST OF REDUCTIONS[12]

\begin{tabular}{|c|c|c|c|c|}
\hline Item & Running hours per year & $\begin{array}{c}\text { Cost of electricity generation } \\
{\left[\mathrm{CNY} \cdot(\mathrm{kW} \cdot \mathrm{h})^{-1}\right]}\end{array}$ & $\begin{array}{l}\text { Cost of reductions } \\
\left(\mathrm{CNY} \cdot t^{-1}\right) \mathrm{CO}_{2} \\
\end{array}$ & $\begin{array}{l}\text { Cost of reductions } \\
\left(\mathbf{U S D} \cdot t^{-1}\right) \mathrm{CO}_{2}\end{array}$ \\
\hline Small Hydropower & 3150 & 0.28 & -114 & -17.6 \\
\hline Big Hydropower & 3300 & 0.24 & -158 & -24.3 \\
\hline Biomass gasification & 6500 & 0.64 & 274 & 42.2 \\
\hline Biomass Direct Combustion & 6000 & 0.66 & 296 & 45.5 \\
\hline Strong Light PV & 1800 & 0.77 & 415 & 63.8 \\
\hline Weak light PV & 1300 & 0.95 & 609 & 93.7 \\
\hline Solar thermal & 2900 & 1.30 & 987 & 151.9 \\
\hline Strong wind power on land & 2096 & 0.41 & 26 & 4.0 \\
\hline Weak wind power on land & 1800 & 0.48 & 102 & 15.6 \\
\hline Offshore wind power & 2600 & 0.53 & 156 & 23.9 \\
\hline
\end{tabular}

TABLE III. CCS CASE GENERATION AND COST OF REDUCTIONS[12]

\begin{tabular}{|l|l|l|l|l|l|}
\hline Case & Type & $\begin{array}{l}\text { Cost of electricity generation } \\
{\left[\mathrm{CNY} \cdot(\mathrm{kW} \cdot \mathrm{h})^{-1}\right]}\end{array}$ & $\begin{array}{l}\text { Quantity of } \mathbf{C O}_{2} \text { emissions } \\
{\left[\mathrm{kg} \cdot(\mathrm{kW} \cdot \mathrm{h})^{-1}\right]}\end{array}$ & $\begin{array}{l}\text { Cost of emissions reductions } \\
\left(\mathrm{CNY} \cdot t^{-1}\right) \mathrm{CO}_{2}\end{array}$ & $\begin{array}{c}\text { Cost of emissions reductions } \\
\left(\mathrm{USD} \cdot t^{-1}\right) \\
\mathrm{CO}_{2}\end{array}$ \\
\hline 1 & Salt water layer & 0.438 & 0.821 & 501 & 77.4 \\
\hline 2 & EOR & 0.298 & 0.821 & -841 & -130.0 \\
\hline 3 & EOR & 0.295 & 0.821 & -869 & -134.3 \\
\hline 4 & Salt water layer & 0.500 & 0.652 & 418 & \\
\hline 5 & EOR & 0.200 & 0.652 & -680 & -105.1 \\
\hline 6 & EOR & 0.138 & 0.652 & -907 & -140.2 \\
\hline
\end{tabular}

\section{B. Impact on energy structure}

Carbon emissions reductions based on CCS technology will not have a big impact on the demand for fossil and nonfossil energy in the existing energy structure, there will not be much effect on energy prices, and the stability of the energy structure will be ensured over a longer period of time.

It will take a long time to develop renewable energy so that they represent a large enough component of the energy structure to meet carbon emissions reductions targets. In the long term, renewable energy substitutes for fossil fuels will change the existing energy structure, the demand for and the prices of these fuels and the fossil-based energy supply.

\section{Impact on energy security}

CCS technology captures, transports, and sequesters carbon dioxide produced through the use of fossil energy, and helps meet the goal of reducing carbon emissions. Therefore, the technology will not change the energy structure, and will not have any impact on energy security.

The use of renewable energy to replace fossil energy, so that the proportion of renewable energy in the total energy structure has increased, which can reduce the country's dependence on imported energy, reduce the risks from energy price fluctuations, enrich national energy diversity, and enhance national energy security.

\section{Impact on the environment}

The application of large-scale CCS technology will significantly reduce carbon dioxide emissions, help to mitigate the greenhouse effect, and also lower emissions of other harmful gases [7]. The technology has a potential impact on the environment and personal health and safety. The impact from the capture process is mainly due to the increased energy consumption and the consequent increase of $\mathrm{NO}_{\mathrm{x}}, \mathrm{SO}_{2}$, and other pollutant emissions. The potential impacts of transport and storage are that $\mathrm{CO}_{2}$ leakage may lead to human poisoning, 
seawater acidification, soil pollution, groundwater pollution, and even induced earthquakes[8]. But there is no potential risk to the environment by replacing fossil fuels with renewable energy to achieve desired reductions in carbon dioxide emissions.

\section{E. Investment and operating costs}

A large initial investment is needed to buy fixed equipment and there are high operating costs[9]. Table 4 shows the change in power efficiency and the cost of power generation after deploying CCS technology in coal-fired power plants.
Deploying CCS technology in coal-fired power plants has led to a significant decline in power plant efficiency $(10.8 \%$ $31 \%$ ), resulting in increased energy consumption. The cost of electricity generation in a coal-fired power plant using CCS technology increased 36\% 93\% compared to a plant without CCS, which directly increases the cost of electricity supplied to businesses and residents and reduces the market competitiveness of CCS coal-fired power plants. Although the initial investment needed for renewable energy sources is higher, the subsequent operating costs are lower which meets the requirements of consumers.

TABLE IV. SYSTEM POWER EFFICIENCY AND POWER GENERATION COST CHANGES CAUSED BY UTILIZING CARBON CAPTURE TECHNOLOGY [12]

\begin{tabular}{|c|c|c|c|c|c|c|}
\hline \multirow{2}{*}{\multicolumn{2}{|c|}{$\begin{array}{l}\text { Capture Technology } \\
\text { Type of technology }\end{array}$}} & \multicolumn{3}{|c|}{ Capture after combustion } & \multirow{3}{*}{\begin{tabular}{|c|}
$\begin{array}{c}\text { Capture } \\
\text { before } \\
\text { combustion }\end{array}$ \\
TPRI \\
7.1 \\
\end{tabular}} & \multirow{3}{*}{$\begin{array}{c}\begin{array}{c}\text { Oxygen-enriched } \\
\text { combustion } \\
\text { capture }\end{array} \\
\text { Super supercritical } \\
8.3\end{array}$} \\
\hline & & \multirow{2}{*}{$\begin{array}{c}\text { Subcritical } \\
11 \sim 12\end{array}$} & \multirow{2}{*}{$\begin{array}{c}\text { Supercritical } \\
11.3 \sim 12.3\end{array}$} & \multirow{2}{*}{$\begin{array}{c}\begin{array}{c}\text { Super } \\
\text { supercritical }\end{array} \\
10.8 \sim 11.8 \\
\end{array}$} & & \\
\hline $\begin{array}{l}\text { Reduction } \\
\text { of system }\end{array}$ & $\begin{array}{c}\text { Absolute drop amplitude } \\
(\%)\end{array}$ & & & & & \\
\hline $\begin{array}{l}\text { efficiency } \\
\text { caused by } \\
\mathrm{CO}_{2} \text { capture } \\
\text { technology }\end{array}$ & $\begin{array}{l}\text { Relative drop amplitude } \\
\qquad(\%)\end{array}$ & 29 31 & 28 31 & $25 \sim 26$ & 16 & 19 \\
\hline \multirow{3}{*}{$\begin{array}{l}\text { The } \\
\text { increase of } \\
\text { generation } \\
\text { cost of } \mathrm{CO}_{2} \\
\text { trapping } \\
\text { power plant }\end{array}$} & $\begin{array}{c}\text { Cost of emission reduction } \\
{\left[\mathrm{CNY} \cdot(\mathrm{MW} \cdot \mathrm{h})^{-1}\right]}\end{array}$ & 545 & 512 & 463 & 413 & 369 \\
\hline & $\begin{array}{l}\text { Cost of emission reduction } \\
\text { [USD }(\mathrm{MW} \cdot \mathrm{h})^{-1} \text { ] }\end{array}$ & 84 & 79 & 71 & 64 & 57 \\
\hline & Increase in amplitude ( $\%$ ) & 93 & 90 & 71 & 52 & 36 \\
\hline
\end{tabular}

\section{F. Scope of application}

CCS technology is mainly applicable to the capture, transportation, and storage of carbon dioxide produced by fossil fuels. Renewable energy is limited by natural conditions, uneven geographical distribution means there is abundant renewable energy in some areas and a shortage in others.

\section{G. Byproducts of emissions reductions}

The potential and economic benefits of $\mathrm{CO}_{2}$ byproducts are very limited. As global economic development continues and CCS applications become more popular, the quantity of $\mathrm{CO} 2$ captured will surpass its industrial demand. As a result, greater quantities of $\mathrm{CO}_{2}$ will have to be sequestered and the market price will remain relatively low, so economic benefits will be greatly reduced. Renewable energy produces almost no carbon dioxide during the production process, nor is there any need to sequester carbon dioxide as a result of power generation.

\section{H. Regulatory Difficulty}

CCS is related to environmental protection, geology, and other aspects of cooperation, but renewable energy regulations are only concerned with grid combination issues which are less problematic.

\section{IV.THE RELATIONSHIP BETWEEN CCS AND RENEWABLE ENERGY}

CCS and renewable energy technologies are equally important in the effort to reduce $\mathrm{CO}_{2}$ emissions and they complement each other.

In the short term, because of energy structure rigidity, the use of fossil fuels to generate energy is dominant so emissions reductions must rely on CCS technology. In the long term, the rapid development of renewable energy will increase its importance in the energy structure and fossil fuels will have a diminishing role. As a result, carbon emissions will be reduced and eventually eliminated, and CCS technology can gradually exit.

\section{POLICY RECOMMENDATIONS ON BOTH OF CCS TECHNOLOGY AND RENEWABLE ENERGY CARBON EMISSION REDUCTION}

It is a long-term and complicated process to increase the proportion of renewable energy in the energy system to enable significant reductions in carbon dioxide emissions in China. CCS technology and renewable energy are both indispensable, but at present, investment risks for CCS technology are higher, and among all the uncertainties, climate policies will have the greatest impact on its development. For developing countries such as China, one necessary condition for developing CCS technology is a carbon emission trading system on emitting 
industries and enterprises such as coal-fired plants[10]. The imposition of a sound carbon trading system can effectively reduce the negative externalities from carbon dioxide emissions, enhance market competitiveness for CCS technology and renewable energy, and promote a low-carbon economy.

Therefore, establishing sound regulatory measures such as a carbon trading system is a prerequisite. The state should simultaneously promote the development of CCS and renewable energy technologies. Including coal-fired power plants with CCS devices in the carbon trading system, where technical reserves of CCS are most important, will reduce $\mathrm{CO}_{2}$ capture costs. The technical reserves are a necessary condition for the commercialization of large-scale CCS technology. The integration of carbon trading system and renewable energy generation and CCS power plant is conducive to improving the market competitiveness of low-emission generators as they can use emissions reductions benefits to better support their own development. This can create a good business environment for the development of CCS and renewable energy technologies.

\section{VI.CONCLUSION}

In conclusion, CCS and renewable energy technologies are equally important in the effort to reduce $\mathrm{CO}_{2}$ emissions.

In order to reduce carbon dioxide emissions effectively, relying on CCS and renewable energy technologies in the short-term, and relying on renewable energy in the long run should be the strategic arrangement.

\section{ACKNOWLEDGMENT}

First of all, I would like to extend my sincere gratitude to my supervisor, Prof. Rong Kang, for her instructive advice and useful suggestions on my paper. I am deeply grateful of her help in the completion of this paper.

Special thanks should go to my friends who have put considerable time and effort into their comments on the draft.

Finally, I am indebted to my parents and wife for their continuous support and encouragement.

\section{REFERENCES}

[1] People's Republic of China for National Economic and Social Development of the 13th Five - Year Plan. 2016, National Development and Reform Commission: China. p. 153. (In Chinese)

[2] $\mathrm{CO}_{2}$, E.r.r.g.o.C.g.s.o., Environmental assessment training textbook on China geological storage of $\mathrm{CO}_{2}$ 1st ed. 2017, Beijing, China: Chemical Industry Press. (In Chinese)

[3] BP. BP Statistical Review of World Energy. 2017; Available from: http://www.bp.com/statisticalreview.

[4] Lang Jin, F.C., "Current situation and trend of renewable energy development in China," Ecological Economy, 2017. 33(10): p. 4. (In Chinese)

[5] Administration, C.N.E., 2016 National renewable energy power development monitoring and evaluation report. 2017. p. 11. (In Chinese)

[6] Lingyun He, M.W., Fang Yin, "Effect of total amount and structure of renewable energy investment on carbon emissions in China," Journal of China university of geosciences(Social sciences edition), 2017. 17(1): p. 13.

[7] Ligong Nie, D.J., A study on the path to global commercialization of CCS technology, ed. 1. 2016, Beijing: Coal industry press. (In Chinese)

[8] CCS in China: Situations Challenges and Opportunities. 2010, The Climate Group: China. p. 71. (In Chinese)

[9] Junyong ZHANG, Y.S., "Prospects on carbon capture and storage (CCS) development," Renewable resources and circular economy, 2013. 6(12): p. 4. (In Chinese)

[10] Zhu, L., "Energy investment modeling and its application under the backgroud of energy security and climate change," Modern management science, 2017. 12: p. 209. (In Chinese) 